\title{
Hepatitis B Envelope Antigen in Children and Adults with Hepatitis B Infection in Tertiary Health Facility in North East Nigeria During the Period 2000-2015
}

Isaac WE ${ }^{1 *}$, J alo I', Ajani $\mathbf{A}^{2}$, Oyeniyi $\mathrm{CO}^{3}$, Abubakar J D ${ }^{4}$, Aremu J T ${ }^{5}$ and Danlami MH $^{6}$

${ }^{1}$ Department of Paediatrics, College of Medical Sciences, Gombe State University, Nigeria

${ }^{2}$ Department of Paediatrics, Federal Teaching Hospital, Gombe, Nigeria

3Infectious Diseases Training and Research group, Gombe, Nigeria

${ }^{4}$ Department of Community Medicine, College of Medical Sciences, Gombe State University, Nigeria

${ }^{5}$ Department of Internal Medicine, Federal Teaching Hospital, Gombe, Nigeria

${ }^{6}$ Department of Medical Microbiology, Federal Teaching Hospital, Gombe, Nigeria

*Corresponding author: Isaac Warnow Elon, Department of Paediatrics, College of Medical Sciences, Gombe State, Nigeria

Received: J une 04, 2021; Accepted: J uly 06, 2021; Published: J uly 13, 2021

\begin{abstract}
Introduction: Worldwide, most people living with chronic HBV infection are in in low- and middle-income countries. Most of the burden of disease from HBV infection comes from infections acquired before the age of 5 years.
\end{abstract}

Materials and Methods: Records of Hepatitis B surface and envelope antigen results of children and adults in Federal Teaching Hospital, Gombe between May 2000 and May 2015 were analyzed

Results: 22,862 individuals were tested for Hepatitis B surface antigen. $19.5 \%$ (4456) tested positive. $24.7 \%$ (3146) and 12.9\% (1310) of males and females respectively were HBsAg positive. HBsAg Peak prevalence of $21.8 \%$ was in the age group 26-46 (2533) and the lowest prevalence in infancy (3.5\%). Amongst males, the 19-25year age group had the peak prevalence of $28.6 \%$ and in females the age group 5-9 years constituted the highest (20.3\%). 36\% (1602/4456) of HBsAg positive children and adults were tested for HBeAg. 26.2\% (420/1602) of individuals with HBsAg carriage were HBeAg. More males (307/1105) than females (113/495) were HBeAg positive but not statistically significant. ( $\mathrm{P}=0.034)$. Prevalence of $\mathrm{HBeAg}$ was highest in infants $(50 \%)$ and children $1-4$ years (50\%) age group and thereafter declined with increasing age. Females of the younger age group <1year, 1-4 years and 5-9 years and older age group, 56-65 and $>65$ years, compared to their male carriers of HBsAg had higher prevalence of $\mathrm{HBeAg}$ but these were not statistically significant.

Conclusion: A fifth of $\mathrm{HBsAg}$ carriers were $\mathrm{HBeAg}$ positive and $\mathrm{HBeAg}$ positivity decreased with increasing age. Hepatitis $B$ vaccination in Nigeria requires urgent strengthening. Keywords: Hepatitis, HBsAg, HBeAg Children, Adults, Nigeria.

\section{Introduction}

Globally, Viral hepatitis caused 1.34 million deaths in 2015, a number comparable to deaths caused by tuberculosis and higher than those caused by Human Immunodeficiency Virus (HIV) [1]. Most viral hepatitis deaths were due to chronic liver disease and primary liver cancer. There were 720000 deaths and 470000 deaths due to cirrhosis and hepatocellular carcinoma respectively [1].

Worldwide, in 2015, an estimated 257 million people were living with Chronic Hepatitis B Virus (CHBV) infection and most living in low- and middle-income countries [1,2].

Hepatitis B infection is endemic in sub-Saharan Africa where $>6.1 \%$ of the general population are chronic carriers of HBV and transmission predominantly occurs in infants and children by perinatal and horizontal routes $[1,3,4]$. The risk of chronic infection peaks when infection is acquired early [1,2]. Most of the burden of disease from $\mathrm{HBV}$ infection comes from infections acquired before the age of 5 years. Therefore, prevention of $\mathrm{HBV}$ infection focuses on children under 5 years of age [2]. Worldwide, the majority of persons with CHBV were infected at birth or in early childhood $[2,3]$.

Immunization is the most effective measure to prevent the transmission of HBV [1,2]. In 2014, the World Health Organization (WHO) reaffirmed the need for hepatitis $\mathrm{B}$ vaccines to become an integral part of national immunization schedules [2]. WHO recommends a birth dose within 24 hours of birth to prevent perinatal and early horizontal HBV transmission $[1,2]$. The birth dose should be followed by 2 or 3 doses of monovalent or multivalent hepatitis $B$ vaccines $[1,2]$.

Access to affordable hepatitis testing is limited. Few people with viral hepatitis have been diagnosed (9\% of $\mathrm{HBV}$-infected persons, 22 million, and $20 \%$ of Hepatitis C Virus (HCV)-infected persons, 14 million) [1]. Infection with HBV may present as either Hepatitis B "e-antigen" ( $\mathrm{HBeAg}$ ) positive or -negative disease. Hepatitis B "e-antigen" is seen in many HBeAg-positive children and young adults, particularly among those infected at birth $[1,2]$.

In persons with $\mathrm{CHB}$, a positive $\mathrm{HBeAg}$ result usually indicates the presence of active HBV replication and high infectivity. Those who are $\mathrm{HBeAg}$ negative, usually anti HBe positive, have lower risk of transmission [1,2]. Being a non-structural protein produced by actively replicating $\mathrm{HBV}, \mathrm{HBeAg}$ is detectable early in the serological course after exposure to HBV, usually after the first months of infection. Clinically, HBeAg is an index of viral replication, infectivity,
J Hepat Res - Volume 6 Issue 1 - 2021

ISSN : 2381-9057 | www.austinpublishinggroup.com

Isaac et al. (C) All rights are reserved
Citation: Isaac WE, Jalo I, Ajani A, Oyeniyi CO, Abubakar JD, Aremu JT, et al. Hepatitis B Envelope Antigen in Children and Adults with Hepatitis B Infection in Tertiary Health Facility in North East Nigeria During the Period 2000-2015. J Hepat Res. 2021; 6(1): 1045. 
inflammation, severity of disease and response to antiviral therapy [5].

In Nigeria, Hepatitis B vaccination was started in 2004 and currently 3 doses are administered at birth, 6 weeks and at 14 weeks [6]. The most recent estimate of Hepatitis $B$ vaccination coverage at birth with valid evidence is $11 \%$ [7] and $49 \%$ for $3^{\text {rd }}$ dose of Hepatitis $B$ vaccine in the country [8].

Demand, supply and systemic side barriers have impacted on vaccination in Nigeria. Low level of community participation, inadequate cold chain infrastructure and poor funding for routine immunization amongst other factors remain barriers to improving immunization coverage in Nigeria [7,8]. A National survey of Hepatitis B in the general population in 2013 of the six geo- political zones of Nigeria showed the national prevalence of $11 \%$ with the highest prevalence of $19 \%$ in Taraba State [9]. The northern zones have higher prevalence rate of Hepatitis B.[9]

Recent Nigeria studies from Jalingo [10], Kaduna [11], Sokoto [12], Kogi [13] and Makurdi [14] showed the prevalence of Hepatitis B Virus of $19.2 \%, 14 \%, 63 \%, 25 \%$ and $39 \%$ in various adult subpopulations of hospital patients respectively. Hepatitis B testing methods were different.

Recent reports [15-22] of Hepatitis B infection in children in Nigeria showed a wide and varying prevalence of $0.5 \%$ to $44.7 \%$. These differences in prevalence could be related to age group, sample size and laboratory method used [23]. However, a pooled analysis of HIV prevalence in children found a prevalence of $11.5 \%$ [23].

In Nigeria, recent studies on dual carriage of HB-surface and Envelope antigens in children[21, 22, 24,] and adults [25-27] have contributed significantly to understanding of the disease but however were limited in sample size, age and sex disaggregation and study duration.

Most of these studies [21,22 24-27] on HBV prevalence and e antigen have used biomarkers such HBsAg and anti-HBc, or the status of Hepatitis $B$ envelope antigen were generally not reported. Hepatitis B envelope epidemiology is crucial and an important marker for perinatal transmission and HBV related disease burden and treatment $[1,2,5]$. The objective of this study is to report the dual carriage of Hepatitis B surface and Envelope antigen in Children and Adult Nigerians from 2000- 2015 in a tertiary health facility.

\section{Methodology}

\section{Study area}

Gombe is the capital of Gombe state. Gombe state is one of the six states that comprise North East Geopolitical zone in the country and one of the geopolitical zones with the highest levels of poverty and worse maternal and child health indices in Nigeria [28].

\section{Study setting}

This study was conducted in Federal Teaching Hospital Gombe, a 500-bed hospital serving Gombe and neighboring states. The Federal Teaching Hospital, Gombe (FTHG) started providing services in the year 2000. It has emerged as a Centre for treatment, teaching and research in the sub region with large patient referrals from the neighboring states of Borno, Yobe, Adamawa and Bauchi.

\section{Study population}

All children and adults who presented to the out-patient departments, and those that were admitted irrespective of their HIV and or Hepatitis C virus status and had Hepatitis B and/or Hepatitis B envelope antigen test conducted from 2000 to 2015.

\section{Laboratory methods}

All children and adults were tested using the Hospital standard for Hepatitis B surface antigen test strip. The ACON HBsAg (ACON Laboratories, Incorporated San Diego, California, USA) is a rapid one step test for the qualitative detection of Hepatitis B surface Antigen and Hepatitis B envelope antigen in serum or plasma. The HBsAg test strip has a relative sensitivity, greater than $99.8 \%$ and specificity of $99.7 \%$.

The ACON HBeAg (ACON Laboratories, Incorporated San Diego, California, USA). The HBeAg EIA Test Kit is a one-step enzyme immunoassay for the qualitative detection of Hepatitis $B$ Envelope Antigen (HBeAg) in human serum or plasma.

\section{Principle}

The ACON HBsAg One Step Test is a qualitative, solid phase, two site sandwich immunoassays for the detection of Hepatitis $B$ surface Antigen (HBsAg) and envelope antigen in serum or plasma. The membrane is pre-coated with anti-HBsAg antibodies on the test line region and anti-mouse antibodies on the control region. During testing the serum or plasma samples reacts with dye conjugate (mouse anti-HBsAg antibody-colloidal gold conjugate) which has pre-coated in the test strip. The mixture migrated upwards on the membrane chromatographically by capillary action to react with anti-HBsAg antibodies on the membrane and generates a red line. Presence of this red line indicates a positive result, while its absence indicates a negative result. Regardless of the presence of HBsAg as the mixtures continues to migrate across the membrane to the immobilized goat anti-mouse region, a red line at the control region will always appear. The presence of this red line serves as verification for sufficient sample volume and proper flow as a control for the reagents [29].

\section{HBeAg principle}

$\mathrm{HBeAg}$ in the sample first bound to anti-HBe antibodies coated on the micro-particles, and then the bound $\mathrm{HBeAg}$ was detected upon addition of anti-HBe antibodies conjugated to alkaline phosphatase. The HBeAg levels were evaluated using ratios of sample to cut-off values (S/CO), and HBeAg positivity was suggested if the S/CO was $\geq 1.0$. Verification of test results was carried out by randomly retesting $5 \%$ of the specimens using the same kit.

\section{Laboratory registers/Data collection}

Records of Hepatitis B surface and envelope antigen results of children and adults in Federal Teaching Hospital, Gombe between 2000 and 2015 were retrieved. Variables analyzed included age, sex, year, month, and hepatitis B surface and envelope antigen.

\section{Data analysis}

All records were imputed into EPInfor Version 3.2 and analysed.

\section{Ethical clearance}

Clearance for this study was received from the Research and Ethical committee of the Federal Teaching Hospital Gombe. 


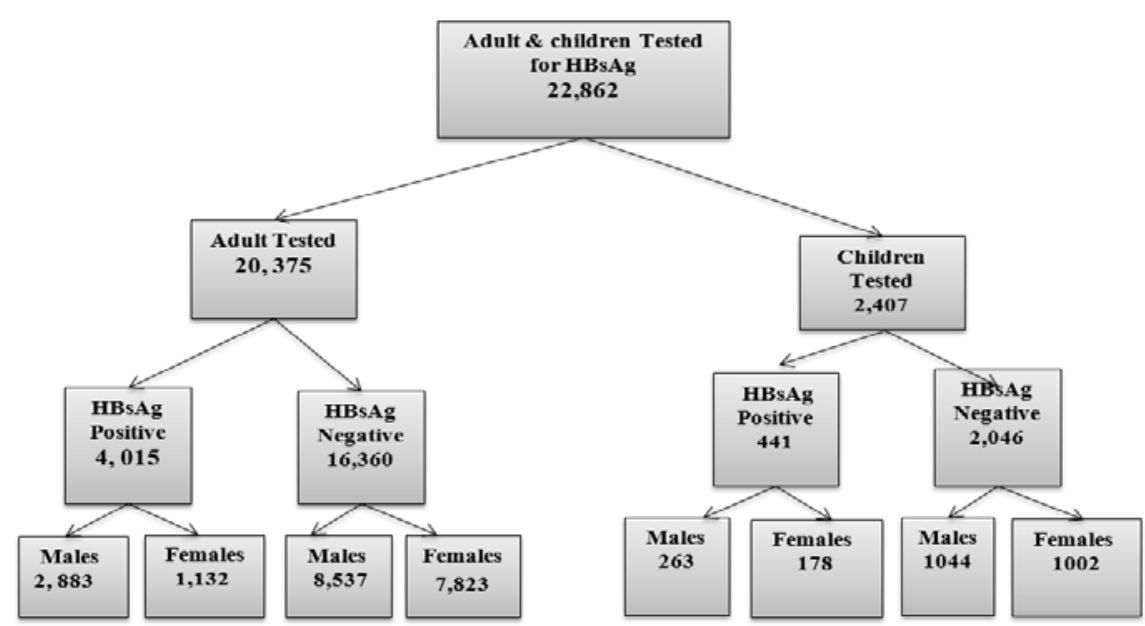

Figure 1: Children and Adult tested for HBsAg during the period 2000-2015.

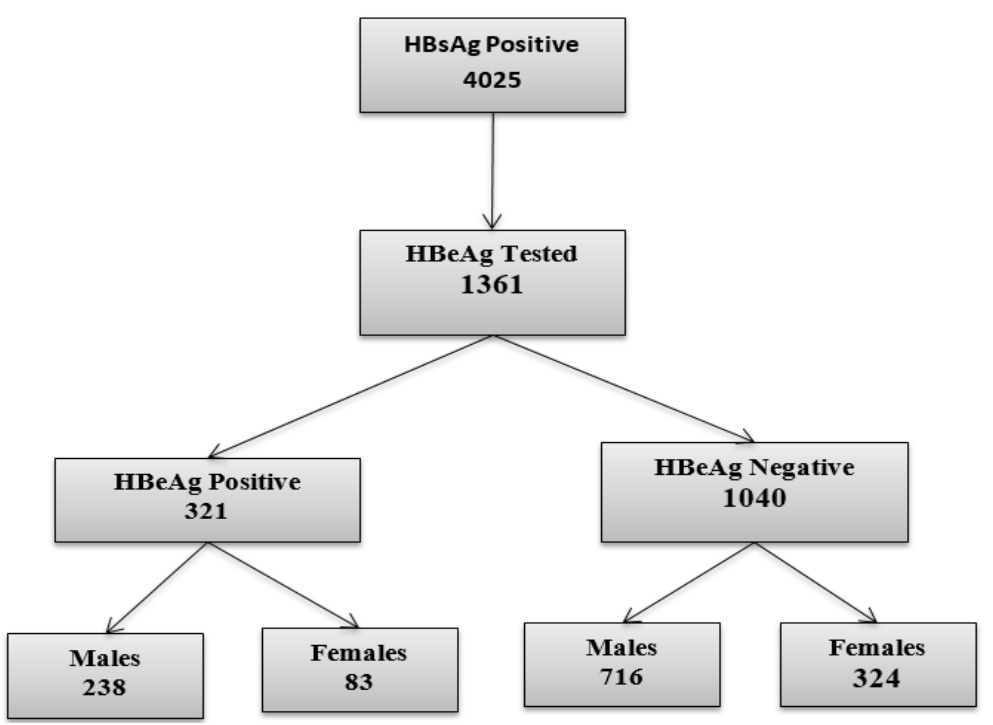

Figure 2: Children and Adult tested for HBeAg in Federal Teaching Hospital Gombe 2000-2015.

\section{Results}

Figure 1 shows the number of children and adults screened for HBsAg in our Health facility during the period 2000- 2015 and Figure 2 the number of HBsAg carriers that were tested for HBeAg.

The overall prevalence of HBsAg was 19.6\%. Children 0-18 years constituted $10.8 \%$ (Table 1). More males than females were tested for HBsAg during the study Period. Males were twice as likely to be HBsAg positive as females. This was statistically significant $(\mathrm{P}=<0.001)$ (Table 1). In children chronic carriage of Hepatitis $\mathrm{B}$ was highest in Adolescents. Figure 3 showed the infection increased with increasing age and remain so throughout adult and elderly age groups. From Adolescents to the older age groups, males had highest HBsAg infection and were twice more likely to be Hepatitis B surface antigen positive than females (Table 2).

Thirty six percent (36\%) of children and adults who were HBsAg positive were tested for the presence of hepatitis B envelop antigen with an overall prevalence of $26.2 \%$ (Table 3). Even though more males were tested for the envelope antigen than females, this was not statically significantly.

The prevalence of HBeAg was highest in infancy and childhood and decreased with decreasing age and this was statistically significant (Table 3). There was no significant difference in the proportion of males and females with the envelope antigen though females had higher prevalence of the e antigen in the early years (Table 4 ) and this was similar for sex and age group categorizations. Figure 4 showed that $\mathrm{HBeAg}$ started declining sharply from 45 years of age until old age.

\section{Discussion}

To the best of our knowledge this study represents the largest number of children and adults tested for HBsAg and HBeAg from a health facility in Nigeria and the sub region. The prevalence of $19.7 \%$ in our study is higher than recent hospital reports of $11.4 \%$ from 
Table 1: Age and Sex distribution of children and adults screened for Hepatitis B 2000-2015.

\begin{tabular}{|c|c|c|c|}
\hline Age distribution & Male & Female & Total \\
\hline$<1$ & $38(0.3)$ & $19(0.2)$ & $57(0.3)$ \\
\hline $1-4$ & $177(1.4)$ & $105(1.0)$ & $282(1.2)$ \\
\hline $5-9$ & $307(2.4)$ & $212(2.1)$ & $519(2.3)$ \\
\hline $10-18$ & $785(6.2)$ & $844(8.3)$ & $1629(7.1)$ \\
\hline $19-25$ & $2019(15.8)$ & $2777(27.4)$ & $4796(21.0)$ \\
\hline $26-45$ & $6714(52.8)$ & $4920(48.5)$ & $11634(50.9)$ \\
\hline $46-55$ & $1381(10.8)$ & $693(6.8)$ & $2074(9.1)$ \\
\hline $56-65$ & $762(6.0)$ & $350(3.5)$ & $1112(4.9)$ \\
\hline$>65$ & $544(4.3)$ & $215(2.1)$ & $759(3.3)$ \\
\hline
\end{tabular}

Table 2: Age and Sex distribution of test results of children and adults screened for HBsAg.

\begin{tabular}{|c|c|c|c|c|}
\hline Sex & $\begin{array}{l}\text { HBsAg Positive } \\
\text { (\%) }\end{array}$ & $\begin{array}{l}\text { HBsAg Negative } \\
\text { (\%) }\end{array}$ & $x^{2}$ & $\mathbf{P}$ \\
\hline \multicolumn{5}{|l|}{ Sex } \\
\hline $\begin{array}{l}\text { Males } \\
\text { Females }\end{array}$ & $\begin{array}{l}3146(24.7) \\
1310(12.9)\end{array}$ & $\begin{array}{l}9581(75.3) \\
8825(87.1)\end{array}$ & 500.094 & 0 \\
\hline $\begin{array}{l}\text { Age group } \\
\text { (Years) }\end{array}$ & & & & \\
\hline $\begin{array}{l}<1 \\
1-4 \\
5-9 \\
10-18 \\
19-25 \\
26-45 \\
46-55 \\
56-65 \\
>65\end{array}$ & $\begin{array}{c}2(3.5) \\
32(11.3) \\
90(17.3) \\
317(19.5) \\
887(18.5) \\
2533(21.8) \\
397(19.1) \\
136(12.2) \\
62(8.2)\end{array}$ & $\begin{array}{c}55(96.5) \\
250(88.7) \\
429(82.7) \\
1312(80.5) \\
3909(81.5) \\
9101(78.2) \\
1677(80.9) \\
976(87.8) \\
697(91.8)\end{array}$ & 163.876 & 0 \\
\hline \multicolumn{5}{|c|}{$\begin{array}{l}\text { Age group and } \\
\text { Sex }\end{array}$} \\
\hline $\begin{array}{l}<1 \text { yr } \\
\text { Male } \\
\text { Female }\end{array}$ & $\begin{array}{l}1(2.6) \\
1(5.3)\end{array}$ & $\begin{array}{l}37(97.4) \\
18(94.7)\end{array}$ & 0.259 & 0.611 \\
\hline $\begin{array}{l}\text { 1- } 4 \text { yrs } \\
\text { Male } \\
\text { Female }\end{array}$ & $\begin{aligned} 23 & (13.0) \\
9 & (8.2)\end{aligned}$ & $\begin{array}{c}154(87.0) \\
96(91.4)\end{array}$ & 1.282 & 0.258 \\
\hline $\begin{array}{l}\mathbf{5 - 9} \text { yrs } \\
\text { Male } \\
\text { Female }\end{array}$ & $\begin{array}{l}47(15.3) \\
43(20.3)\end{array}$ & $\begin{array}{l}260(84.7) \\
169(79.7)\end{array}$ & 2.164 & 0.141 \\
\hline $\begin{array}{l}\mathbf{1 0 - 1 8} \text { yrs } \\
\text { Male } \\
\text { Female }\end{array}$ & $\begin{array}{l}193(24.6) \\
124(14.7)\end{array}$ & $\begin{array}{l}592(75.4) \\
720(85.3)\end{array}$ & 25.403 & 0.001 \\
\hline $\begin{array}{l}19-25 \text { yrs } \\
\text { Male } \\
\text { Female }\end{array}$ & $\begin{array}{l}577(28.6) \\
310(11.2)\end{array}$ & $\begin{array}{l}1442(71.4) \\
2467(88.8)\end{array}$ & 235.217 & 0 \\
\hline $\begin{array}{l}\text { 26-45 yrs } \\
\text { Male } \\
\text { Female }\end{array}$ & $\begin{array}{c}1869(27.8) \\
664(15.6)\end{array}$ & $\begin{array}{l}4845(72.2) \\
4256(84.4)\end{array}$ & 342.875 & 0 \\
\hline $\begin{array}{l}46-55 \text { yrs } \\
\text { Male } \\
\text { Female }\end{array}$ & $\begin{array}{l}299(21.7) \\
98(14.1)\end{array}$ & $\begin{array}{c}1082(78.3) \\
595(85.9)\end{array}$ & 16.813 & 0 \\
\hline $\begin{array}{l}56-65 \text { yrs } \\
\text { Male } \\
\text { Female }\end{array}$ & $\begin{array}{l}96(12.6) \\
40(11.4)\end{array}$ & $\begin{array}{l}666(87.4) \\
310(88.6)\end{array}$ & 0.306 & 0.58 \\
\hline $\begin{array}{l}>65 \text { yrs } \\
\text { Male } \\
\text { Female }\end{array}$ & $\begin{array}{l}42(7.7) \\
20(9.3)\end{array}$ & $\begin{array}{c}502(92.3) \\
195(90)\end{array}$ & 0.514 & 0.473 \\
\hline
\end{tabular}

Kano [30] and 14\% from Kaduna [11] but comparable to $19.2 \%$ from Jalingo [10] however lower than reports of $25 \%$ in Kogi [13], 39\% in Makurdi [14] and 63\% from Sokoto [12]. In all these reports the proportion of children was small and overall sample sizes were also small compared to our study.

Our study prevalence is higher than the Hepatitis B pooled
Table 3: Age and Sex distribution of children and adults $\mathrm{HBsAg}+$ and tested for HBeAg.

\begin{tabular}{|l|c|c|c|c|}
\hline \multicolumn{1}{|c|}{ Sex } & $\begin{array}{c}\text { e Antigen Tested } \\
\text { (\%) }\end{array}$ & $\begin{array}{c}\text { e Antigen Not tested } \\
\text { (\%) }\end{array}$ & $\mathbf{X}^{2}$ & P \\
\hline Sex & & & & \\
\hline Males & $1106(35.2)$ & $2040(64.8)$ & 2.943 & 0.086 \\
\hline Females & $496(37.9)$ & $814(62.1)$ & & \\
\hline Age & & & & \\
group & & $0(0.0)$ & & \\
\hline$<1$ & $2(100)$ & $14(43.8)$ & & \\
$1-4$ & $18(56.2)$ & $42(46.7)$ & & \\
$5-9$ & $48(53.3)$ & $144(45.4)$ & & \\
$10-18$ & $173(54.6)$ & $545(61.4)$ & 112.32 & $<0.001$ \\
$19-25$ & $342(38.6)$ & $1692(66.8)$ & & \\
$26-45$ & $841(33.2)$ & $253(63.7)$ & & \\
$46-55$ & $144(36.3)$ & $108(79.4)$ & & \\
$56-65$ & $28(20.6)$ & $56(90.3)$ & & \\
$>65$ & $6(9.7)$ & & & \\
\hline
\end{tabular}

Table 4: Age and Sex distribution of children and adults $\mathrm{HBsAg}+$ and $\mathrm{HBeAg}$ positive.

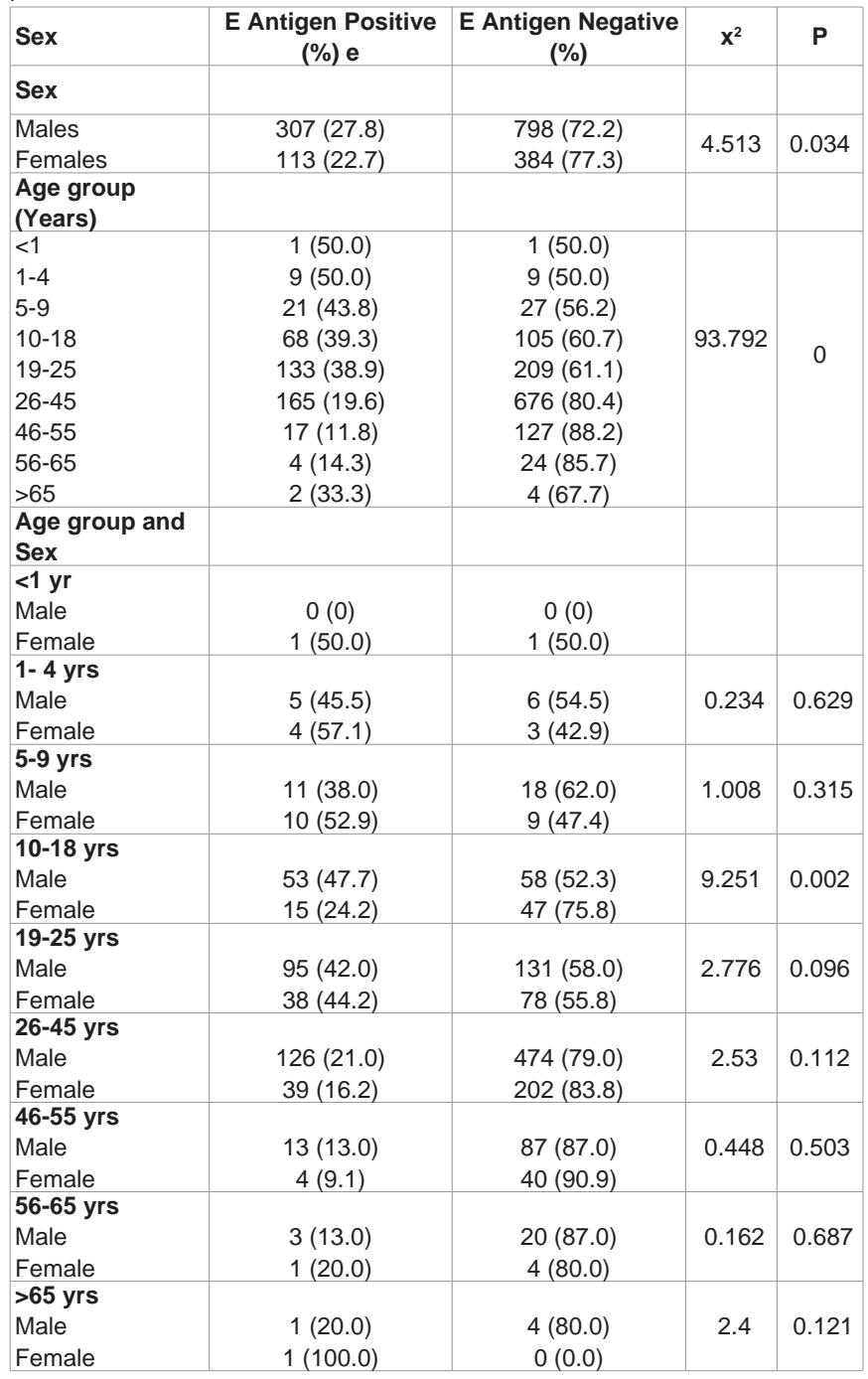

prevalence of $14 \%$ in various adult subgroups and $11.5 \%$ in children in Nigeria between 2000 to 2013 by Musa et al in a systematic review and meta-analysis [23]. It is higher than the $12.2 \%$ [31] prevalence in the National survey of Hepatitis B in the general population in the country in 2016. While these differences in HBV prevalence rates in Nigeria were attributed to different testing method, sample size, age 


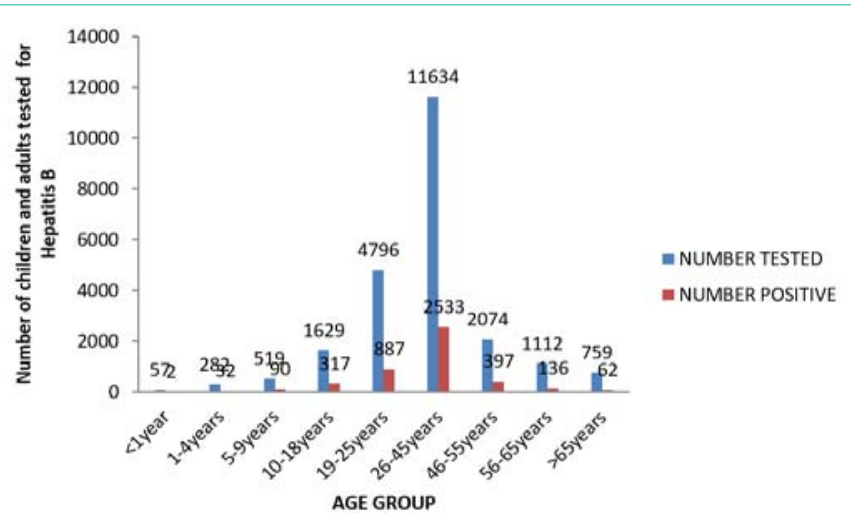

Figure 3: Children and adults tested for Positive for HBsAg 2000-2015.

groups and region of the country [23] our higher prevalence report would be related to our region, the North East Sub region of Nigeria. This region has the lowest vaccine coverage, poorest maternal and child health indices with highest poverty levels of any of the 6 subregions in the country [6-8].

While Health facility data have shown higher prevalence, rates linked to symptomatic subjects compared to community reports and despite varying rates, Nigeria like the rest of sub-Saharan African countries is hyperendemic for Hepatitis B where prevalence is greater than $8 \%$ in the general population [1-4].

Systematic review and meta-analysis of Hepatitis B prevalence between 1995 and 2018 in Burkina Fasso,[32] Ghana [33], Cameroon [34] and Malawi [35] reported prevalence of $11.2 \% ; 12 \%, 11.2 \%$ and $8.1 \%$ respectively. HBsAg reports in children were lacking in these country reviews.

However recent studies of Hepatitis B in different children's populations in the West African sub-region reported prevalence of $12.3 \%$ in Ghana [36], 13.7\% in Sierra Leone [37], 20.5\% in Cameroon [38] and $4 \%$ in Cote Dviore [39]. These reports had small sample sizes, limited sex and age ranges and short study duration, but contributory to HBV epidemiology in the region.

While our study subjects comprised of volunteers, patients and children who may or may not have been immunized, the prevalence of Hepatitis B in our study is high. This high prevalence could be related to low level of routine immunization coverage of $23 \%$ and specifically of Hepatitis b vaccine in Gombe State and Nigeria respectively [6,7]. In addition some of our study subjects were recruited before the introduction of Hepatitis B Vaccine in Nigeria in 2004.

A significantly high prevalence of hepatitis B in proportion of children below five years in our study suggests perinatal transmission due to lack of immunization or early childhood transmission $[1,2]$.

HBsAg carriage increased with increasing age peaking in adolescents in children and in young adults with highest prevalence in adults in the reproductive age group and subsequently declining.

Earlier [40-42] and recent reports [43-47] from Nigeria and studies from Ghana [36], Sierra Leone [37], Cameroon [38], and Cote D'viore [39] showed age-related increase in prevalence of HBsAg.

Most Hepatitis B Virus (HBV) infections in Sub-Saharan African

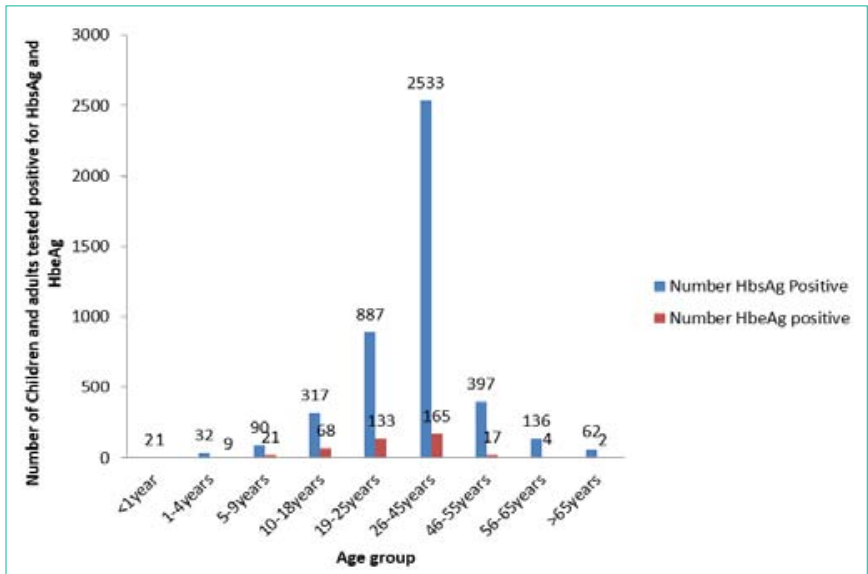

Figure 4: Chronic HBsAg carrier Children and Adult positive for HBeAg.

infants and children are acquired through horizontal transmission $[48,49]$. At least $50 \%$ of infections in children cannot be accounted for by mother-to-infant transmission and, in many endemic regions, prior to the introduction of neonatal vaccination, the prevalence peaked in children $7-14$ years of age $[1,2]$.

In especially endemic areas, Children infected perinatally with Hepatitis B can be a source of horizontal infection for siblings and playmates [50,51]. Intra-familial horizontal transmission of Hepatitis $\mathrm{B}$ can occur during sharing of; bath towels, chewing gum or candies, toothbrushes and biting of finger nails in conjunction with scratching the backs of carriers of HBsAg [52].

Adolescents infected during childhood or in this period with HBV are at risk of infecting others especially through sexual transmission as it is a dominant route of horizontal transmission during adolescence $[53,54]$.

Common risk factors for hepatitis B infection in the Nigeria National survey were uvulectomy, presence of tribal marks, sharing of sharp objects, and circumcision, which is performed traditionally on many Nigerian males [23].

In both children and adult subjects, more males than females were twice as likely to be infected with HBV. Plasma clearance rate for $\mathrm{HBsAg}$ in males is slower compared to females and females were said to have elaborated more antibodies to HBsAg than males. Differences in tribal and sexual behaviour between males and females may account for higher percentage of HBsAg positive males with HBV chronic infection [55,56]. An Altered Pattern of Liver Apolipoprotein A-I Isoforms is implicated in male chronic Hepatitis B progression [57].

In West Africa, Shimakawa Y et al. [58] reports that earlier age at $\mathrm{HBV}$ infection is associated with an increased risk of Hepatocellular carcinoma through persistence of viral replication and Seroconversion of HBsAg is uncommon and occurs at a rate of about $1 \%$ per year [59].

$\mathrm{HBeAg}$ estimates are crucial for understanding the epidemiology of HBV and for prioritizing access to treatment for chronic HBV infection especially in the wake of WHO scaling of early diagnosis and treatment $[2,5,60]$. 
Before the availability of The HBV Combo Rapid Test Cassette Kit for the rapid diagnosis of $\mathrm{HBsAg}$ and other markers of hepatitis $\mathrm{B}$ (HBeAg; AbHBe, AbHBs and $\mathrm{AbHBc}$ ), kits for hepatitis $\mathrm{b}$ and envelope antigen were separate in our environment. It's probable a combination of factors of cost of envelope antigen test, low level of awareness on the significance of $\mathrm{HBeAg}$ and or inadequate patient counseling $[1,2]$ accounted for why only a third of HBsAg carriers tested for this marker of viral replication, infectivity, inflammation, severity of disease and response to antiviral therapy

The overall prevalence of hepatitis B envelope antigen in children and adult HBsAg carriers was $26.2 \%$ in our study. There is paucity of comparable reports on $\mathrm{HBeAg}$ status in children and adult chronic carriers of Hepatitis B virus especially in Nigeria and the sub region.

However Forbi et al. [24] in central Nigeria reported HBeAg prevalence of $72.7 \%$ and $42.3 \%$ in 22 children $<10$ years old and 10-20 years respectively, while a prevalence of $27 \%$ was reported in Zaria Nigeria by Sani et al. [22] amongst 95 children with Hepatitis B disease.

The expression of HBeAg is one of the major factors influencing the frequency and mode of transmission of HBV [5,59-61].

Ott et al. [61] in 1990 reported Hepatitis Be prevalence of 55.6\% and $42.2 \%$ in females of $0-9$ years and $10-19$ years respectively in the West Africa sub region. Our study prevalence rate of $65 \%$ in the age group 0-9 is higher than the report by Ott et al. [61]. In the adolescent females, Hepatitis Be prevalence of $22 \%$ in our study is lower than $42 \%$ reported by Ott et al. Our sample size in this age group was smaller. Fifteen years later, in 2005 Ott et al. [61] showed prevalence of $\mathrm{HBeAg}$ of $55.3 \%$ in $0-9$ years and $41.1 \%$ in $10-19$ year females.

Like our study finding, $\mathrm{HBeAg}$ in $\mathrm{HBsAg}$ carriers declined with increasing age in some studies with females in our report predominating though not statistically significant $[24,59,61]$.

HBeAg reports in children with chronic HBV from Brazil [62], USA and Canada [63] of $66.3 \%$ and $74 \%$ respectively were generally higher than our study finding. In the Brazilian study [62], the highest envelope antigen prevalence of $69.5 \%$ was in children $0-4$ years thereafter declining to $50 \%$ in children $15-18$ years of age.

During the natural course of chronic Hepatitis B Virus (HBV) infection, patients with high serum levels of viral DNA and hepatitis $\mathrm{B}$ e antigen ( $\mathrm{HBeAg})$ may gradually and spontaneously clear $\mathrm{HBeAg}$ and develop antibody to $\mathrm{HBeAg}$ [64]. In contrast to HBeAg loss, clearance of HBsAg rarely occurs in patients with chronic hepatitis $B$, the annual rate of HBsAg clearance in adults was reported to be $0.5-0.8 \%$ [65]. In African countries, HBeAg seroconversion is more frequent, occurring at an annual rate of $14-16 \%$ and half losing it by puberty $[5,59,66]$.

In highly endemic HBV endemic areas, earlier studies showed that while about half of HBsAg positive children remain hepatitis $\mathrm{B}$ e antigen ( $\mathrm{HBeAg}$ )-positive into their twenties in Taiwan in subSaharan Africa the prevalence of $\mathrm{HBeAg}$ among $\mathrm{HBsAg}$ positive people declines to $10 \%$ in the second decade of life $[67,68]$,

While there is dearth of studies similar to ours, studies of HBeAg in Adults with chronic HBV in Nigeria were generally limited by sample size, duration, age and sex disaggregation. However, earlier reports of HBeAg of $16.4 \%$ by Amazigo in Eastern Nigeria [69]; 8.8\% by Abiodun et al. in Benin City, South of south of Nigeria [70]; 10.8\% in Ibadan by Otegbayo et al. [71] and $11.9 \%$ by Lesi et al in Lagos [72] in South West Nigeria; $19 \%$ by Ola et al. [73] and 8.6\% Ijoma et al. [74] both in Enugu, Eastern Nigeria were lower than our study finding.

Recent reports of HBeAg from Lagos by Akinbami et al. [75] Forbi et al. [24] Odimayo [76] and Mbaawuaga et al. [77] both from Makurdi in Central Nigeria of $8.2 \%, 19.2 \%, 3 \%$ and $9.3 \%$ respectively were generally twice as lower than our finding.

However higher Prevalence of $\mathrm{HBeAg}$ of $62.5 \%, 30.3 \%$, were reported by Yakasaai et al. [25] and Mbaawuaga et al. [78] respectively in pregnant women with chronic HBV infection. Equally high $\mathrm{HBeAg}$ prevalence of $30.7 \%$ and $26.2 \%$ in women were reported by Yakassai et al. [25] and Francisca et al. [27].

These high $\mathrm{HBeAg}$ in pregnant women and indeed females of reproductive age have significant implications for perinatal transmission in Nigeria and indeed Sub-Saharan Africa where HBV is not routinely tested in ANC; neonatal $\mathrm{HBV}$ vaccine coverage is low and Hepatitis B immunoglobulin is scarce $[1,2,79,80]$.

These reports in Nigeria were indeed limited by sample size, age and sex distribution and study duration in demonstrating age and sex related $\mathrm{HBeAg}$ prevalence when compared with our study.

Persistence of high HBV viral load or envelope antigenaemia plays an important role in increasing the risk of primary liver cancer $[81,82]$.

Among other factors, $\mathrm{HBeAg}$ expression is influenced by HBV genotypes and sub genotypes [5,83,84]. Sub Saharan Africa has a low rate of $\mathrm{HBe}$ prevalence amongst chronic hepatitis B carriers. On average, $\mathrm{HBeAg}$ seroconversion usually occurs in children younger than 15 years and carriers of HBV sub genotypes A1, genotypes D and E seroconvert early $[5,83,84]$.

$\mathrm{HBeAg}$ sero-clearance occurs faster than HBsAg sero-clearance in chronically infected persons $2-15 \%$ versus $1 \%$ per year [85]. Maternal $\mathrm{HBeAg}$ and genotype $\mathrm{C}$ were associated with delayed HBeAg seroconversion [86].

Chronic HBV carriers with $\mathrm{HBeAg}$ seroconversion before age 30 have excellent prognosis, whereas patients with delayed $\mathrm{HBeAg}$ seroconversion after age 40 have significantly higher incidences of HBeAg-negative hepatitis, cirrhosis, and Hepatocellular carcinoma [87].

A West African, study [59] reported age-specific prevalence of $\mathrm{HBeAg}$ at baseline decreased with increasing age; of the $173 \mathrm{HBeAg}-$ positive carriers at baseline, $82.1 \%$ lost $\mathrm{HBeAg}$ and the clearance rate was $66.4 \%$ per year.

Rufai et al. [88] and Rashmi et al. [89] respectively reported Hepatitis Be antigen of $13.3 \%$ among blood donors in Ghana and $12.8 \%$ in India among chronic Hepatitis B surface antigen carriers. In a comprehensive review of the prevalence of HBV sero-markers in subpopulation groups across the 14 regions of WHO, Merrill et al. [90] demonstrated that HBsAg and HBeAg testing methods affected prevalence. This observation was also reported by Musa et al. [23] in 
national review of HBV in Nigeria. This study [90] reported a wide variation in Hepatitis Be antigen prevalence amongst WHO subregions.

While only a third of chronic HBV carriers tested for HBe antigen in our study, thereby underestimating its prevalence, the utility of $e$ antigen in the treatment decision in sub-Saharan Africa has recently been proposed by Shimakawa et al. [60].

\section{Conclusion}

Our study generally showed that HBV infection in young and productive adult Nigerians is high and at least a fifth had HBeAg a marker of severe disease which decreased with increasing age. The implications for health are profound and especially for Hepatitis B prevention, control and treatment.

\section{Limitation of the Study}

Our limitations are several. We couldn't determine if HBsAg was new or chronic infection (carriage of HBsAg for greater than 6 months) and Anti HBS and Anti-Hbc would have determined previous exposure and the need for preventive HBV vaccine in our subjects. The limitation of study is further related to our inability to report other parameters pertaining liver function, liver status using biopsy, or fibro scan or viral load with which we would be able to define better patients' status. Some of these capacities like viral load and biopsy have only been recently acquired (2018) in our facility and majority of the subjects are unable to pay for these services

\section{Recommendations}

Hepatitis B vaccination and indeed Routine immunization requires urgent strengthening and legislation making immunization in Nigeria mandatory must be a top legislative agenda.

A prospective and longitudinal multi Centre study on Viral Hepatitis that is nationally representative is needed in Nigeria to define further epidemiologic burden and of Viral Hepatitis in the country to inform policy, planning, and treatment.

\section{Author Contributions}

Elon Warnow Isaac: Conceived of the study and study design, conducted quantitative analysis developed the first manuscript draft, and critically reviewed all drafts of the manuscript.

Jalo Iliya, Alkali Yaya and Ajani Ayomikun: Oversaw the study design and critically reviewed and commented on the final manuscript.

Abubakar Joshua Difa, Oyeniyi Christianah: Conducted quantitative analysis and commented on all drafts of the manuscript.

Aremu John and Danlami Halilu: Oversaw data and critically reviewed and commented on the final manuscript.

\section{Acknowledgment}

We wish to acknowledge Hajiya Fatima Y Aliyu and Hajiya Zainab Danmalam of the data unit of Paediatrics department for extracting the data.

\section{References}

1. World Health Organization Guidelines for the prevention, care and treatment of persons with chronic hepatitis B infection. World Health Organization. 2015.

2. World Health Organization. Global hepatitis report 2017. World Health Organization. 2017

3. MacLachlan JH, Locarnini SC, Benjamin C. Estimating the global prevalence of hepatitis B Lancet. 2015; 386: 10003,1515-1517.

4. Zampino R, Boemio A, Sagnelli C, Alessio L, Adinolfi LE, Sagnelli E, et al. Hepatitis B virus burden in developing countries. World J Gastroenterol. 2015; 21: 11941-11953

5. Kramvis A. The clinical implications of hepatitis B virus genotypes and $\mathrm{HBeAg}$ in pediatrics. Rev Med Virol. 2016; 26: 285-303.

6. National Programme on Immunization and Partners. Five years National Strategic Plan 2003-2007. National Programme on Immunization. 2002; 19 20.

7. Nigeria: WHO and UNICEF estimates of immunization coverage: 2016 revision. 2016.

8. National Bureau of Statistics (NBS) and United Nations Children's Fund (UNICEF). Multiple Indicator Cluster Survey 2016-17, Survey Findings Report. Abuja, Nigeria: National Bureau of Statistics and United Nations Children's Fund. 2017.

9. Federal Ministry of Health. Prevalence survey of hepatitis $B$ and $C$ in general population. FMOH. 2013.

10. Omote V, Kashibu E, Ojumah I, Adda D, Etaghene J, Ukwamedua H. Serological screening of hepatitis $B$ virus and hepatitis $C$ virus among patients attending a tertiary hospital in Jalingo, Taraba state, Nigeria. Saudi J Health Sci. 2018; 7: 167-171.

11. Edia-Asuke UA, Abubakar Z, Asuke S Seroprevalence of Hepatitis B Infection among out Patients Attending a Public Tertiary Hospital in Kaduna State Nigeria. Trop Med Surg. 2015: 3: 189.

12. Bello HS, Isa MA, Shettima A, Allamin IA. Prevalence of serological markers for acute Hepatitis B Virus among patients attending Sokoto Specialist Hospital, Sokoto, Nigeria. J Microbiol Biotech Res.2013; 3: 132-135.

13. Sule WF, Okonko IO, Yumusa IP, Odu NN, Frank-Peterside N. Hepatitis B Surface Antigen ( $\mathrm{HBsAg}$ ) and risk factors of transmission among patients attending hospital in Ankpa, Kogi State, Nigeria. Nature and Sci. 2011; 9: 37-41.

14. Amuta EU, Houmsow RS, Sar TT, Awodi EM. Seroprevalence of Hepatitis B among hospital patients in Makurdi Metropolis, Benue State, Nigeria. Inter J Bio Pharm Allied Sci. 2012; 1: 29-35.

15. Sadoh AE, Ofili A. Hepatitis B infection among Nigerian children admitted to a children's emergency room. African Health Sciences. 2014; 14: 377-383.

16. Jibrin B, Jiya NM, Ahmed H. Prevalence of Hepatitis B surface Antigen in children with sickle cell anemia. Sahel Med J. 2014; 17: 15-18.

17. Donbraye E, Japhet MO, Adesina AO, Abayomi OA. Prevalence of asymptomatic hepatitis $B$ virus surface antigenemia in children in llesha, Osun state, south-Western Nigeria. Afr J Micro Res. 2014; 8: 2329-2331.

18. Uleanya ND, Obidike EO. Prevalence and risk factors of hepatitis B virus transmission among children in Enugu, Nigeria. Nig J Paediatr .2015; 42 : 3.

19. Eke CB, Ogbodo SO, Ukoha OM, Ibekwe RC, Asinobi IN, Ikefuna AN, et al. Seroprevalence and Risk Factors of Hepatitis B Virus Infection among Adolescents in Enugu, Nigeria. J Trop Pediatr. 2015; 61: 407-413.

20. Ikobah J, Okpara H, Elemi I, Ogarepe Y, Udoh E, Ekanem E. The prevalence of hepatitis $B$ virus infection in Nigerian children prior to vaccine introduction into the National Programme on Immunization schedule. Pan Afr Med J. 2016; 23: 128.

21. Ndako JA, Onwuliri FC, Botson ID, et al. Studies on the serological markers of hepatitis $B$ virus infection among children in Riyom LGA, North Central Nigeria. Int J Health Sci Res. 2016; 6: 405-414.

22. Sani MM, Hafsat WI, Sakinatu MA, Ibrahim A, Sani M, Alhassan MY. 
Prevalence of hepatitis B viral infection at paediatric gastroenterology clinic of ABUTH, Zaria. Niger J Basic Clin Sci. 2018; 15: 114-117.

23. Musa BM, Bussell S, Borodo MM, Samaila AA, Femi OL. Prevalence of hepatitis B virus infection in Nigeria, 2000-2013: a systematic review and meta-analysis. Nig J Clinical Practice. 2015; 18: 163-172.

24. Forbi JC, Iperepolu OH, Zungwe T, Agwale SM. Prevalence of Hepatitis B e Antigen in Chronic HBV Carriers in North-central Nigeria. J Health Popul Nutr. 2012; 30: 377-382.

25. Yakasai IA, Ayuba R, Abubakar IS, Ibrahim SA. Sero-prevalence of hepatitis $B$ virus infection and its risk factors among pregnant women attending antenatal clinic at Aminu Kano teaching hospital, Kano, Nigeria. J Basic Clin Reprod Sci. 2012; 1: 49-55

26. Okeke KN, Ella EE, Jatau ED. Prevalence of Hepatitis B surface antigen ( $\mathrm{HbsAg}$ ) among pregnant women attending University Health Services (sickbay) A.B.U. Zaria. Ann Exper Bio. 2015; 3: 1-4

27. Francisca OU, Ihongbe JC, Ifeanyi OE, et al. Evaluation of Some Immunological and Haematological Indices of Hepatitis B Infected Subjects in Nnamdi Azikiwe University Teaching Hospital, Nnewi, Anambra State Nigeria. J Biomed Sci. 2017; 6: 3.

28. National Bureau of Statistics (NBS) and United Nations Children's Fund (UNICEF). Multiple Indicator Cluster Survey 2016-17, Survey Findings Report. Abuja, Nigeria: National Bureau of Statistics and United Nations Children's Fund. 2017.

29. World Health Organization. Anti HBs test. 2019.

30. Nwokedi EOP, Odimayo MS, Emokpae AM, Yahaya IA, Sadiq MN, Okwori EE. Seroprevalence of Hepatitis B Surface Antigen among patients attending Aminu Kano Teaching Hospital. Nig J Med. 2010; 19: 4

31. Olayinka AT, Oyemakinde A, Balogun MS, et al. Seroprevalence of Hepatitis B Infection in Nigeria: A National Survey. Am J Trop Med Hyg. 2016; 95 902-907.

32. Lingani M, Akita T, Ouoba S, et al. High prevalence of hepatitis B infections in Burkina Faso (1996-2017): a systematic reviews with meta-analysis of epidemiological studies. BMC Public Health. 2018; 18: 551

33. Ofori-Asenso R, Agyeman AA. Hepatitis B in Ghana: a systematic review \& meta-analysis of prevalence studies (1995-2015). BMC Infect Dis. 2016 16: 130

34. Bigna JJ, Amougou MA, Asangbeh SL, et al. Seroprevalence of hepatitis B virus infection in Cameroon: a systematic review and meta-analysis. BMJ Open. 2017; 7: 6

35. Stockdale AJ, Mitambo C, Dean Everett D, Geretti AM, Gordon MA Epidemiology of hepatitis B, C and D in Malawi: systematic review. BMC Infect Dis. 2018; 18: 516.

36. Amidu N, Alhassan A, Obirikorang C, et al. Sero-prevalence of Hepatitis B surface (HBsAg) antigen in three densely populated communities in Kumasi, Ghana J Med Biomed Sci. 2012; 1: 59-65.

37. Ansumana R, Dariano DF, K HJacobsen et al. Seroprevalence of Hepatitis B Surface Antigen (HBsAg) in Bo, Sierra Leone, 2012-2013. BMC Res Notes. 2018 11: 113.

38. Foupouapouognigni $Y$, Mba SAS, Betsem a 'Betsem, et al. Hepatitis B and C Virus Infections in the Three Pygmy Groups in Cameroon. J Clini Micro. 2011.

39. Attia KA, Kissi YH, Doffou S, et al. Prevalence of hepatitis B infection and factors associated in children of Ivorian HBsAg carrier subjects. Open J Gastroenterol. 2013, 3: 237-240.

40. Abiodun PO, Omoike IU. Hepatitis B antigenaemia in children in Benin City Nig J Paed. 1990; 17: 27-31.

41. Abiodun PO, Okolo SN. Hepatitis B surface antigenamia in and outpatient children at University of Benin Teaching Hospital. Nig J Paediatr. 1991; 18 105-112.

42. Bada AS, Olatunji PO, Adewuyi JO, Iseniyi JO, Onile BA. Hepatitis B surface antigenaemia in Ilorin, Kwara State, Nigeria. Cent Afr J Med. 1996
42:139-141.

43. David OM, Oluduro AO, Ariyo AB, Ayeni D, Famurewa O. Sero-epidemiological survey of hepatitis $B$ surface antigenaemia in children and adolescents in Ekiti State, Nigeria. J Publ H and Epid. 2013; 5: 11-14.

44. Sadoh AE, Ofili A. Hepatitis B infection among Nigerian children admitted to a children's emergency room. African Health Sciences. 2014; 14: 377-383.

45. Jibrin B, Jiya NM, Ahmed $\mathrm{H}$. Prevalence of Hepatitis B surface Antigen in children with sickle cell anemia. Sahel Med J. 2014; 17: 15-18.

46. Donbraye E, Japhet MO, Adesina AO, Abayomi OA. Prevalence of asymptomatic hepatitis B virus surface antigenemia in children in llesha, Osun state, south-Western Nigeria. Afr J Micro Res. 2014; 8: 2329-331.

47. Uleanya ND, Obidike EO. Prevalence and risk factors of hepatitis B virus transmission among children in Enugu, Nigeria. Nig J Paediatr. 2015; 42.

48. Edmunds WJ, Medley GF, Nokes DJ, et al. Epidemiologic patterns of Hepatitis $B$ Virus (HBV) in highly endemic areas. Epidemiol Infect. 1996; 117: 313-325.

49. Martinson FE, Weigle KA, Royce RA, Weber DJ, Suchindran CM, Lemon SM Risk factors for horizontal transmission of hepatitis $B$ virus in a rural district in Ghana. Am J Epidemiol. 1998; 147: 478-487.

50. Hsu SC, Chang MH, Ni YH, Hsu HY, Lee CY. Horizontal transmission of hepatitis B virus in children. J Pediatr Gastroenterol Nutr. 1993; 16: 66-69.

51. Whittle HC, Bradley AK, McLauchlan K, et al. Hepatitis B virus infection in two Gambian villages. Lancet. 1983; 1: 1203-1206.

52. Burnett RJ, Francois G, Kew MC, et al. Hepatitis B virus and human immunodeficiency virus co-infection in sub-Saharan Africa: a call for further investigation. Liver Inter. 2005; 25: 201-213.

53. Jacobs B, Mayaud P, Changalucha J, et al. Sexual transmission of hepatitis B in Mwanza, Tanzania. Sex Trans Dis. 1997; 24: 121-126.

54. Banla AK, Gani KT, Halatoko WA, Layibo Y, Akolly K, et al. Prevalence of the Surface Antigen of Hepatitis B Virus among Youth Aged 15 to 24 in TOGO in 2010. J Infect Dis Ther. 2015; 3: 238.

55. Price H, Dunn D, Zachary T, Vudriko T, Chirara M, Kityo C, et al. Hepatitis B serological markers and plasma DNA concentrations. AIDS. 2017; 31: 11091117.

56. Coursaget P, Yvonnet B, Chotard J, Vincelot P, Sarr M, Diouf C, et al. Ageand sex-related study of hepatitis $B$ virus chronic carrier state in infants from an endemic area (Senegal). J Med Virol. 1987; 22: 1-5.

57. Yang F, Yin Y, Wang F, Zhang L, Wang Y, Sun S. An Altered Pattern of Liver Apolipoprotein A-I Isoforms is implicated in male chronic Hepatitis B progression. J Proteome Res. 2010; 9: 134-143.

58. Shimakawa Y, Yan HJ, Tsuchiya N, Bottomley C, Hall AJ. Association of early age at establishment of chronic hepatitis $B$ infection with persistent viral replication, liver cirrhosis and hepatocellular carcinoma: a systematic review. PLoS One. 2013; 8: e69430.

59. Shimakawa Y, Lemoine M, Njai HF, et al. Natural history of chronic HBV infection in West Africa: a longitudinal population-based study from The Gambia. Gut. 2016; 65: 2007-2016.

60. Shimakawa Y, Njie R, Ndow G, et al. Development of a simple score based on $\mathrm{HBeAg}$ and $\mathrm{ALT}$ for selecting patients for HBV treatment in Africa. J Hepatol. 2018; 69: 776-784.

61. Ott JJ, Stevens JA, Wiersma ST. The risk of perinatal hepatitis B virus transmission: hepatitis $\mathrm{B}$ e antigen $(\mathrm{HBeAg})$ prevalence estimates for all world regions. BMC Infect Dis 2012; 12: 131.

62. Chachá SGF, Ferreira SC, Costa TV, et al. Clinical, demographic and epidemiological characteristics of patients with hepatitis B followed at a university hospital in southeastern Brazil predominance of $\mathrm{HBeAg}$ negative cases. Rev Socied Brasil Med Trop. 2011; 44: 13-17.

63. Schwarz KB, Cloonan YK, Ling SC. Children with Chronic Hepatitis B in the United States and Canada. J Pediatr. 2015; 167: 1287-1294.

64. Chiu Y-C, Liao S-F, Wu J-F, Lin C-Y, Lee W-C, Chen H-L, et al. Factors 
Affecting the Natural Decay of Hepatitis B Surface Antigen in Children with Chronic Hepatitis B Virus Infection during Long-Term Follow-Up. J Pediatr. 2014; 165: 767-772.

65. Tseng TC, Liu CJ, Su TH, Wang CC, Chen CL, Chen PJ, et al. Serum hepatitis B surface antigen levels predict surface antigen loss in hepatitis B e antigen seroconverters. Gastroenterol. 2011; 141: 517-525.

66. Hadziyannis SJ. Natural history of chronic hepatitis B in Euro-Mediterranean and African countries. J Hepatol. 2011; 55: 183-191.

67. Chu CM, Liaw YF. Chronic hepatitis B virus infection acquired in childhood: special emphasis on prognostic and therapeutic implication of delayed HBeAg seroconversion. J Viral Hepat. 2007; 14: 147-152.

68. Mendy ME, McConkey SJ, van der Sande MAB, Crozier S, Kaye S, et al Changes in viral load and HBsAg and HBeAg status with age in HBV chronic carriers in The Gambia. Virol J. 2008; 5: 49.

69. Amazigo UO, Chime AB. Hepatitis-B virus infection in rural and urban populations of eastern Nigeria: prevalence of serological markers. East Afr Med J. 1990; 67: 539-544.

70. Abiodun PO, Olomu A, Okolo SN, Obasohan A, Freeman O. The prevalence of hepatitis Be antigen and anti-HBE in adults in Benin City. West Afr J Med. 1994; 13: 171-174.

71. Otegbayo JA, Fasola FA, Abja A. Prevalence of hepatitis B surface and e antigens, risk factors for viral acquisition and serum transaminase among blood donors in Ibadan, Nigeria. Trop Gastroenterol 2003; 24: 196-197.

72. Lesi OA, Kehinde MO, Omilabu SA. Prevalence of the hepatitis B "e" antigen in Nigerian patients with chronic liver disease. Niger Q J Hosp Med. 2004; 14: $1-4$

73. Ola SO, Otegbayo JA, Yakubu A, Aje AO, Odaibo GN, Shokunbi W. Pitfalls in diagnosis of hepatitis $\mathrm{B}$ virus infection among adults Nigerians. Niger $\mathrm{J}$ Clin Pract. 2009; 12: 350-354.

74. Ijoma UN, Nwokediuko SC, Onyenekwe B, Ijoma CK. Low prevalence of hepatitis B 'E' antigen in asymptomatic adult subjects with hepatitis B virus infection in Enugu, South East Nigeria. Internet J Gastroenterol. 2009; 10: 1.

75. Akinbami et al. Seroprevalence of Hepatitis B e antigen (HBe antigen) and B core antibodies (IgG anti-HBcore and IgM anti-HBcore) among hepatitis $B$ surface antigen positive blood donors at a Tertiary Centre in Nigeria. BMC Research Notes. 2012; 5: 167.

76. Odimayo M.S; Nwadioha S. I, Nwokedi E. Prevalence of HbeAg among Hepatitis B seropositive individuals in Makurdi, Nigeria. Am J Bio Chem Pharm Sci. 2013; 1: 8.
77. Mbaawuaga EM, Enenebeaku MNO, Okopi JA, Damen JG. Hepatitis B Virus (HBV) infection among pregnant women in Makurdi, Nigeria. Afr J Biomed Res. 2008; 11: 155-159.

78. Mbaawuaga EM, Iroegbu CU, Ike AC. Hepatitis B Virus (HBV) Serologica Patterns in Benue State, Nigeria. Open J of Med Microbiol. 2014; 4: 1-10.

79. Keane E, Funk AL, Shimakawa Y. Systematic review with meta-analysis: the risk of mother-to-child transmission of hepatitis $B$ virus infection in subSaharan Africa. Aliment Pharmacol Ther. 2016; 44: 1005-1017.

80. Shimakawa $Y$, Bottomley $\mathrm{C}, \mathrm{Njie} \mathrm{R}$, et al. The association between materna hepatitis $\mathrm{B}$ e antigen status, as a proxy for perinatal transmission, and the risk of hepatitis B e antigenaemia in Gambian children. BMC Public Health. 2014; 14: 532 .

81. Chen YC, Chu CM, Liaw YF. Age-Specific Prognosis Following Spontaneous Hepatitis B e Antigen Seroconversion in Chronic Hepatitis B. Hepatol. 2015; 51: $435-444$.

82. Chen CJ, Yang $\mathrm{HI}$, Su J, Jen CL, You SL, et al. Risk of hepatocellula carcinoma across a biological gradient of serum hepatitis B virus DNA level. JAMA. 2006; 295: 65-73.

83. Kramvis A, Kew MC. Epidemiology of hepatitis B virus in Africa, its genotypes and clinical associations of genotypes. Hepatol Res. 2007; 37: 9-19.

84. McMahon BJ. The influence of hepatitis B virus genotype and sub genotype on the natural history of chronic hepatitis B. Hepatol Int. 2009; 3: 334-342.

85. Liaw YF, Chu CM. Hepatitis B virus infection. Lancet. 2009 373: 582-592.

86. Tseng YR, Wu JF, Ni YH, Chen HL, Chen CC, et al. Long-term effect of maternal $\mathrm{HBeAg}$ on delayed $\mathrm{HBeAg}$ seroconversion in offspring with chronic hepatitis B infection. Liver Int 2011; 31: 1373-380.

87. Chen YC, Chu CM, Liaw YF. Age-specific prognosis following spontaneous hepatitis B e antigen seroconversion in chronic hepatitis B. Hepatol. 2010; 51: 435-444.

88. Rufai T, Mutocheluh M, Kwarteng K, Dogbe E. The prevalence of hepatitis B virus $\mathrm{E}$ antigen among Ghanaian blood donors. Pan Afr Med J. 2014; 17: 53

89. Rashmi KS, Syeda MK, Ravikumar KL. Profile of Hepatitis B 'e' Antigen and Antibodies to Hepatitis B 'e' Antigen in Hepatitis B Seropositive Patients at a Tertiary Care Hospital in Bengaluru, India. Inter J Sci Study. 2015; 3: 5-8

90. Merrill RM, Hunter BD. Seroprevalence of markers for hepatitis B viral infection. Inter J Infect Dis. 2011; 15: 78-121. 